\title{
The Potential Dissemination of Radicalism Ideology of Islamic State of Iraq and Syria (ISIS) in Higher Education
}

\author{
Muhammad Azil Maskur \\ Anti-Radicalism and Terrorism Studies Center, Faculty of Law, Universitas Negeri Semarang (UNNES), Indonesia \\ Email: azilmaskur85@mail.unnes.ac.id
}

\begin{abstract}
Indonesia is the largest Muslim country with the largest quantity in the world. This fact makes all organizations that struggle for establishment of the Islamic Caliphate (khilafah islamiyah) considering Indonesia as main target. One of the world's concerns today is the threat of Islamic State of Iraq and Syrian (ISIS) organization, which is fighting for Islamic caliphate through the path of radicalism. The spread of ISIS's radical ideology turned out to have arrived in Indonesia, especially younger generation, and not least of those that led to terrorism.
\end{abstract}

Keywords-Ideology; Radicalism; ISIS

\section{INTRODUCTION}

Ideology comes from Latin, which is ideos and logis. Ideos is a thought and logos means science, or logis meaning logic. Therefore, the notion of ideology according to Ali Syariati in [4] is the science of beliefs and ideals. Thus if someone has believed in an ideology, then it has been imprinted in his/her heart and will be fought for even though many obstacles stand in the way.

As something that believed, it certainly brings a great desire in every person or certain group to expand and develop the adopted ideology. It is not surprising that the United States with a free-market ideology better known as capitalism also continues to force itself both intentionally and involuntarily, both planned and unplanned to all elements of society in the world, as well as other countries in the world such as the Soviet Union, Saudi Arabia, Iran, Israel and others.

In the present day, ideological development has been prominently rapid and diverse, even within a nation there are several believed ideologies, which may come from understanding diversity as well as from the encompassing social realities such as retardation, progress, modernity, oppression and so forth.

Development and dissemination of ideology is inseparable from the campus setting and young generation. Campus is a higher education institution where learners are called students. The average age of students in the area is 18 (eighteen) to 22 (twenty-two) years old. This means that it is young age. In addition, the campus is a meeting place for people who are concerned in academics. It is certainly that an existence of academic freedom and freedom of academic forum, campus is main objective of ideological development.

History records that young people and campus academic setting always drive every change. Young people drove the entire struggle for the nation's independence preparation, all the way to proclamation of independence, annihilation of communist ideology, to the reformation event. This historical reality is all evidence of the role of youth in materializing the desired changes in the national components. It also raises a historical conclusion that if one wants any change; it must be necessary to start initially from transformation of young generation.

Many figures cannot deny the role of youth. If history had noted the strategic role of youth with regard to dissemination of ideology, some national leaders express the same thing these days. Setya Novanto (Chairperson of the Indonesian House of Representatives) revealed that Indonesia needs young people to solve all the problems of the nation because in addition to have strong physical strength, young people also have brilliant thoughts and extraordinary enthusiasm to seek and solve the problems[10]. Imam Nahrawi stated on various occasions that this was conveyed in a public lecture at UIN Surabaya [11]. There are still many other national figures state that the role of youth is highly important.

The Youth, in Law Number 40 of 2009 concerning Youth is defined as an Indonesian citizen entering an important period of growth and development. The age of youth in the Law is between 16 (sixteen) to 30 (thirty) years old. This age if converted into the age of formal education are those who mostly attend Senior High Schools/Vocational Schools and those on campus are undergraduate and graduated students, as well as those who are still productively fresh graduates. Although some Indonesian youths do not attend formal schools, some may still go to informal schools such as the Salaf Islamic Boarding School. Some young people who have no education, such as in rural areas that are far from access to secondary education. From classification of youth age, which is 16-30 years, the most vital role is to play a function in the class of policy makers or say the least the youth group that is capable of influencing the community are those who hold a position and have status as educated students, such as college students and fresh graduates. 
Therefore, position of young people in campus is significantly vital, as the two youth groups, both college students and fresh graduates are those attending the campus or who have experienced living in a campus.

The vital role of young people must be their own attraction by a group or group of people who wish for their ideology to be widespread in various parts of the world. There are positive and negative ideologies to bring out and believe, some bring peace and some have an effect on damage, hatred and lead to hostility.

\section{RESEARCH METHOD}

This paper comes from empirical juridical research using a non-doctrinal approach. The empirical juridical approach is intended to find out the effectiveness of the existing legal policy challenged with the latest community problems. This means analyzing existing laws and regulations related to the issue of radicalism then juxtaposed with problems in the field with the raised research problems, then analyzed and become a conclusion that is the answer to the problem (Zainuddin, 2010:12).

Non-doctrinal approach according to Soetandyo Wingjosoebroto (in Zainuddin, 2010: 13) is a research in the form of empirical studies to discover a theory. This non-doctrinal approach can be used to examine the raised issues in which the problem has been separated from the context of existing normative regulations or even no existing normative policies.

\section{RESULT AND DISCUSSION}

\section{A. Facts on the Dissemination of Radicalism and Terrorism in Indonesia}

Indonesia is a big country, although it consists of various tribes, religions, races and groups but has agreed to employ the ideology of Pancasila for unifying the nation in the context of the Unitary State of the Republic of Indonesia. The position of Pancasila besides being the national ideology, it has the state of national grundnorm. Hans Kelsen addressed the term of grundnorm or fundamental norm as basic norm in a country that becomes a foothold in making the norms subordinate to it (Jimly, 2006:170).

Lately, we have been shocked by the growing spread of ISIS ideology. An ideology that is synonymous with violence in the name of religion. In fact, before the existence of ISIS ideology, Indonesia had recorded several incidents caused by the development of ideology in addition to the Pancasila ideology, which was the G/30/S/PKI Rebellion, and the DII/TII rebellion led by Kartosoewiryo.

This Islamic State of Iraq and Syria (ISIS) was born in fact on the understanding of Islam which most scholars consider to have misinterpreted the Qur'an and Hadith regarding Jihad, thus giving birth to radical thoughts which led to acts of terrorism.
Indonesia has been the target of terrorism crimes. The following is a series of terrorism cases in Indonesia from the data in electronic media:

\begin{tabular}{|c|c|c|c|}
\hline No & $\begin{array}{l}\text { Date of } \\
\text { Event }\end{array}$ & Events and Locations & Victim \\
\hline 1 & $28 / 3 / 1981$ & $\begin{array}{l}\text { Garuda Indonesia } \\
\text { aircraft were hijacked } \\
\text { by } 5 \text { people using } \\
\text { weapons from } \\
\text { Komando Jihad. }\end{array}$ & $\begin{array}{l}2 \text { people died (crew and } \\
\text { passengers), and } 3 \\
\text { terrorists were killed }\end{array}$ \\
\hline 2 & $21 / 1 / 1985$ & $\begin{array}{l}\text { Motive of "jihad" } \\
\text { terrorism at } \\
\text { Borobudur Temple }\end{array}$ & - \\
\hline 3 & $1 / 8 / 2000$ & $\begin{array}{l}\text { A bomb exploded in } \\
\text { the Philippine } \\
\text { ambassador }\end{array}$ & $\begin{array}{l}2 \text { people died and } 21 \\
\text { people were injured (in } \\
\text { which there was the } \\
\text { Philippine Ambassador } \\
\text { for Indonesia, Leonides } \\
\text { T. Canay) }\end{array}$ \\
\hline 4 & $27 / 8 / 2000$ & $\begin{array}{l}\text { Bomb at the } \\
\text { Malaysian } \\
\text { ambassador's office }\end{array}$ & No victims \\
\hline 5 & $13 / 9 / 2000$ & $\begin{array}{l}\text { Bomb at Jakarta } \\
\text { Stock Exchange } \\
\text { Building (P2) }\end{array}$ & $\begin{array}{l}\text { More than } 100 \text { victims, } \\
10 \text { of them died and } \\
\text { hundreds of cars were } \\
\text { badly damaged }\end{array}$ \\
\hline 6 & $24 / 12 / 2000$ & $\begin{array}{l}\text { Bombs exploded in } \\
\text { several cities in } \\
\text { Indonesia on } \\
\text { Christmas Eve }\end{array}$ & $\begin{array}{l}16 \text { people died, } 96 \\
\text { people were seriously } \\
\text { and lightly injured, and } \\
37 \text { units of cars were } \\
\text { damaged }\end{array}$ \\
\hline 7 & $22 / 7 / 2001$ & $\begin{array}{l}\text { Bombs at HKBP } \\
\text { Nyawa and Santa } \\
\text { Anna Church }\end{array}$ & 5 people died \\
\hline 8 & $23 / 9 / 2001$ & $\begin{array}{l}\text { Bomb exploded at } \\
\text { Plaza Atrium Senen } \\
\text { DKI Jakarta }\end{array}$ & $\begin{array}{l}6 \text { people who were } \\
\text { lightly injured }\end{array}$ \\
\hline 9 & $12 / 10 / 2001$ & $\begin{array}{l}\text { Bomb exploded at } \\
\text { fast food restaurants, } \\
\text { KFC Makassar }\end{array}$ & No casualties \\
\hline 10 & $6 / 11 / 2001$ & $\begin{array}{l}\text { Bomb exploded in } \\
\text { the courtyard of AIS } \\
\text { (Australian } \\
\text { International School) }\end{array}$ & No casualties \\
\hline 11 & $1 / 11 / 2002$ & $\begin{array}{l}\text { Bomb Blast in the } \\
\text { Bulungan area of } \\
\text { Jakarta }\end{array}$ & \\
\hline 12 & $1 / 1 / 2002$ & $\begin{array}{l}\text { Four bombs exploded } \\
\text { at several churches in } \\
\text { Palu, Central } \\
\text { Sulawesi }\end{array}$ & No casualties \\
\hline 13 & $12 / 10 / 2002$ & Bali Bombing 1 & $\begin{array}{l}202 \text { people died, } 300 \\
\text { people were injured } \\
\text { (Most victims were } \\
\text { Australians) }\end{array}$ \\
\hline 14 & $5 / 12 / 2002$ & $\begin{array}{l}\text { Bomb exploded at } \\
\text { fast food restaurant } \\
\text { under the } \\
\text { McDonald's Makasar } \\
\text { trademark }\end{array}$ & $\begin{array}{l}11 \text { people were injured, } 3 \\
\text { people died }\end{array}$ \\
\hline 15 & $3 / 2 / 2003$ & $\begin{array}{l}\text { Bomb in the lobby of } \\
\text { Bhayangkari Jakarta } \\
\text { Police Headquarters }\end{array}$ & ( \\
\hline 16 & $27 / 4 / 2003$ & $\begin{array}{l}\text { Bomb exploded at } \\
\text { terminal } 2 \mathrm{~F} \text { of } \\
\text { Soekarno-Hatta } \\
\text { International Airport }\end{array}$ & $\begin{array}{l}\text { This incident took } 10 \\
\text { victims, } 2 \text { of them were } \\
\text { seriously injured and the } \\
\text { rest only suffered minor } \\
\text { injuries }\end{array}$ \\
\hline 17 & $5 / 8 / 2003$ & $\begin{array}{l}\text { Bomb at JW Marriott } \\
\text { Hotel Jakarta }\end{array}$ & $\begin{array}{l}\text { Dozens of people died } \\
\text { and hundreds more } \\
\text { people were injured }\end{array}$ \\
\hline 18 & $\begin{array}{l}\text { January } 10, \\
2004\end{array}$ & Palopo bomb & $\begin{array}{l}4 \text { People killed in this } \\
\text { incident }\end{array}$ \\
\hline 19 & September & Australian Embassy & 5 people died, hundreds \\
\hline
\end{tabular}




\begin{tabular}{|c|c|c|c|}
\hline & 9,2004 & Bomb & $\begin{array}{l}\text { were injured, and several } \\
\text { buildings nearby were } \\
\text { affected }\end{array}$ \\
\hline 20 & $\begin{array}{l}\text { December } \\
12,2004\end{array}$ & $\begin{array}{l}\text { Immanuel Church } \\
\text { bomb in Palu, } \\
\text { Central Sulawesi }\end{array}$ & - \\
\hline 21 & $\begin{array}{l}\text { March 21, } \\
2005\end{array}$ & $\begin{array}{l}\text { Two bombs exploded } \\
\text { in Ambon city }\end{array}$ & No casualties were found \\
\hline 22 & $\begin{array}{l}\text { May 28, } \\
2005\end{array}$ & Tentena Bomb & 22 people were killed \\
\hline 23 & $\begin{array}{l}\text { June } 8, \\
2005\end{array}$ & $\begin{array}{l}\text { Bomb exploded in } \\
\text { Pamulang }\end{array}$ & No casualties \\
\hline 24 & $\begin{array}{l}\text { October } 1, \\
2005\end{array}$ & Bali Bomb II & $\begin{array}{l}22 \text { people were killed } \\
\text { and } 102 \text { injured }\end{array}$ \\
\hline 25 & $\begin{array}{l}\text { December } \\
31,2005\end{array}$ & $\begin{array}{l}\text { Bomb at a market in } \\
\text { Palu, Central } \\
\text { Sulawesi }\end{array}$ & $\begin{array}{l}8 \text { people were killed and } \\
45 \text { people were injured }\end{array}$ \\
\hline 26 & 2009 & $\begin{array}{l}\text { Two bombs exploded } \\
\text { concurrently at JW } \\
\text { Marriott and Ritz- } \\
\text { Carlton (Jakarta) }\end{array}$ & - \\
\hline 27 & $\begin{array}{l}\text { April 15, } \\
2011\end{array}$ & $\begin{array}{l}\text { Suicide bombings } \\
\text { were detonated at } \\
\text { Malporesta Mosque }\end{array}$ & $\begin{array}{l}\text { This incident killed the } \\
\text { bombers and injured } 25 \\
\text { people }\end{array}$ \\
\hline 28 & $\begin{array}{l}\text { September } \\
25,2011\end{array}$ & $\begin{array}{l}\text { Suicide Bombing at } \\
\text { Kepunton Solo } \\
\text { Church }\end{array}$ & $\begin{array}{l}\text { One bomber was killed } \\
\text { in this incident while } 28 \\
\text { others were injured }\end{array}$ \\
\hline 29 & $\begin{array}{l}\text { August 17, } \\
2012\end{array}$ & $\begin{array}{l}\text { The shooting of Eid } \\
\text { (Lebaran) security } \\
\text { posts in Gemblengan } \\
\text { Solo }\end{array}$ & No casualties \\
\hline 30 & $\begin{array}{l}\text { August 18, } \\
2012\end{array}$ & $\begin{array}{l}\text { Grenade Exploded in } \\
\text { Pospam Gladak Solo }\end{array}$ & No casualties \\
\hline 31 & $\begin{array}{l}\text { August } 30 \\
2012\end{array}$ & $\begin{array}{l}\text { Attack on Singosaren } \\
\text { Police Station, Solo }\end{array}$ & No casualties \\
\hline 32 & $\begin{array}{l}\text { August 28, } \\
2016\end{array}$ & $\begin{array}{l}\text { Suicide Bomb Trial } \\
\text { in Medan }\end{array}$ & Injuring the pastor \\
\hline 33 & $\begin{array}{l}\text { January } 14, \\
2016\end{array}$ & $\begin{array}{l}\text { Bomb at Jl, Thamrin } \\
\text { Jakarta }\end{array}$ & 8 people died \\
\hline 34 & July 5, 2016 & $\begin{array}{l}\text { Bomb in Mapolresta } \\
\text { Solo }\end{array}$ & $\begin{array}{l}1 \text { person was killed } \\
\text { (perpetrator), } 1 \text { police } \\
\text { was injured }\end{array}$ \\
\hline 35 & $\begin{array}{l}\text { May 24, } \\
2017\end{array}$ & $\begin{array}{l}\text { Bomb in Kampung } \\
\text { Melayu, Jakarta }\end{array}$ & 3 Police officers died \\
\hline 36 & July 8,2017 & $\begin{array}{l}\text { Pan bomb in } \\
\text { Bandung }\end{array}$ & $\begin{array}{l}\text { No casualties (Bomb } \\
\text { exploded at the suspect's } \\
\text { house before being used } \\
\text { for acts of terrorism) }\end{array}$ \\
\hline 37 & $\begin{array}{l}\text { May 8-9, } \\
2018\end{array}$ & $\begin{array}{l}\text { Terror Action at } \\
\text { Brimob Mako }\end{array}$ & $\begin{array}{l}5 \text { Police were killed, } 1 \\
\text { Terrorist was killed, } \\
\text { several police were } \\
\text { injured }\end{array}$ \\
\hline 38 & $\begin{array}{l}\text { May 13, } \\
2018\end{array}$ & Bomb in Surabaya & 14 people died \\
\hline
\end{tabular}

Source: Data was processed from various printed and electronic media

From a series of acts of terrorism, all of them were caused by misunderstanding of the religion that they have received. Their understanding of terrorists against religion is different from the understanding of Islam that had been taught at Islamic boarding schools in Indonesia. Initially it was not directly set in the act of terrorism, but this misunderstanding of religion initially made radical people who were very potentially to fall prey to terrorist acts, which according to the perpetrators' beliefs were called Jihad.

Considering phenomenon of the series of terrorism events, it can be concluded that radical movements in Indonesia have developed rapidly. Most terrorists claim to carry out his actions in the name of
Jihad. The following is an acknowledgments of one of terrorists which is Azmi Fuadi alias Anton aka Septi born in Bandung, September 13, 1992, graduating from Darussyahada Islamic Boarding School in 2009, who was ever involved in the muahidin city and deko network (Dede Kodrat, Poso), and also joined the abu roban network. Anton, together with other fellow terrorists, carried out bombing activities with the aim of upholding God's sentence and monotheism in the earth, including: first, being involved in the Beji Bomb, Anton took part in assembling the bomb with Anwar. This bomb was aimed at the bombing that Toriq will carry out. This act was called Amaliah Istisyaidah to murder anshoru thogut and infidel persons in Indonesia, that they are deterred and repented of their disbelief. Second, being involved in making bombs that Salim alias Diaz carried and threw at the Police Station in Mitra Batik Tasikmalaya. Anton believed that this was legitimate to avenge for his brothers who had been shot to death by Indonesian thogut in Cigondewah Bandung. Third, being involved in planning the shooting of police at Cirendeu conducted by Nurul Haq, Fauzy, Dayat and Hendi with the aim of killing soldiers who were considered thogut in Indonesia that their blood was halal. Fourth, involved in the shooting of police in Ciputat whose perpetrators were the same as the police shooting in Cirendau. The purpose of this action was the same as killing the army of the unbelievers thogut $n$ Indonesia. Fifth, involved in the group that carried out the bombing of Rajapolah Tasikmalaya District Police (Bomb maker were Anton, Nurul Haq and Hendi). They had a purpose of combating Indonesian infidel country. Sixth, Vihara Ekayana Bombing. Performed by Anton (assembler), NH (assembler), Hendi (assembler), Dayat and Fauzy (bomb button pushers). They intended to defend the Ikhwanul(s) in Myanmar as they were inhumanely persecuted by Buddhists. Seventh, the shooting of police in Pondok Aren, Anton did not participate, the perpetrators were Nurul Haq, Fauzy, Hendi and Dayat. It aimed to eradicate thogut, terrorizing the Indonesian thogut. The eighth carried out a robbery at Bank Rakyat Indonesia (BRI) Panongan Tanggerang. The goal was that BRI is logistics of infidel government stated to be halal for amaliah funds [12].

Recognition was obtained from phenomenal actor of Bali Bombing perpetrators, the Bali Bomb Trio, namely Amrozi, Imam Samudera and Muklas who considered what they were doing was jihad. Even in their funerals, many people believed that they were martyrs as there was a "black bird" karomah bird circulating during funerals. It was explained in the website eradajjal.blogspot.co.id, barisanjihad.blogspot.com, www.youtube.com/watch?v=gdsDFa1MgIA

http://www.muslimdaily.net, http://jannatullah. blogspot.co.id. In these sites it was stated firmly that they were martyred. This certainly makes people affected by misconceptions between terrorism and jihad.

The development of dissemination of radical ideology potentially lead to terrorism has expanded in cyberspace, that the National Counterterrorism Agency has requested Kominfo (The Communication and Information) 
to block sites that are considered radical. These sites include indonesiasupportislamicatate.blogspot.com, shoutussalam.com, arrahmah.com, voa-islam.com, ghur4ba.blogspot.com, panjimas.com, thoriquna.com, dakwatuna.com, an-najah.net, muslimdaily.net, salamonline.com, aqlislamiccenter.com, kafilahmujahid.com, kiblat.net, dakwahmedia.com, muqawamah.com, lasdipo.com, gemaislam.com, eramuslim.com, daulahislam.com, azzammedia.com, and hidayatullah.com (kominfo.go.id).

Those sites in the statement of the Head of BIN (Indonesian State Intelligence Agency), at the time was Marciano Norman, argued that the freezing of those sites was an attempt to prevent the development of ISIS in Indonesia. The closure was also intended in an effort to shut down those sites access, which is now extremely wide-ranging and unrestricted to influence the people that lead to radicalism and it ends by justification for terrorism, and finally to recruit terrorists.

The Islamic State of Iraq and Syria (ISIS) is centered in the Middle East precisely in Syria, but its movement is sensed to have entered Indonesia. This is in accordance with the purpose of the establishment of ISIS as stated by former NASA intelligence member Edward Snowden, which is to unite all components of Jihad groups from various countries [8].

The threat of ISIS entering Indonesia is actually predictable, this is because there are several community groups in Indonesia that are in line with the occurrence of ISIS such as Abu Bakar Baasyir who wrote his agreement letter with ISIS that his followers would practically obey and agree as well. According to Jalaludin Rahmat (Member of the House of Representatives Commission VIII who is also a Muslim scholar) stated that there are Islamic organizations which have the same establishment as ISIS, including Hizb ut-Tahrir Indonesia and Mujahideen Group (http://obsessionnews.com/kang-jalalormas-yang-ingin-dirikan-negara-islam-sama-dengan-isis)

In line with what Jalaludin Rahmat stated, Chairman of the National Counterterrorism Agency Arsyad Mbai alleged that there were several concentrations of terrorist groups scattered throughout the nation, thus it is necessary to beware after the ISIS declaration in Syria. The group is the Qoidah Aminah in North Sumatra and Aceh, which consists of the Dulmatin (Jamaah Islamiyyah/JI) group, Abdullah Sonata (the Compact/Crisis Management Committee), Mustofa (Jamaah Anshorut Tauhid/JAT), and the Western Indonesian Mujahid group based in Lampung, NII on the island of Borneo, the Eastern Indonesian Mujahid led by Daeng Koro Santoso in Poso, Asmar group in Sulawesi, there was a group of Walid in Ambon, JAT in Bali, and the Bima NTB Group, there were Western Indonesian Mujahids (MIB) in Java led by Abu Omar and Abu Roban, NII in Tasikmalaya, and the network group in Central Java. All these terrorism networks are responsible for the involvement of 56 Indonesian citizens who joined ISIS radical groups [8].

The existence of Indonesian citizens who are members of ISIS has begun to be subject of discussions and certainty after the emergence of Abu Muhammad Al Indonesiy, one of the alumni of the Aceh Jihad Tandim led by Abu Roban and the Indonesian Navy Attimimi Salim from Malang East Java resident on Youtube who made statement as ISIS jihadist. In the video Salim cited 2 (two) Alquran verses, namely [8].

Say: "if your fathers, children, brothers, wives, family
members, wealth that you work for, your trade that you are
concerned about its loss, and a place to live that you hold
dear, are the ones you love more than Allah and His
Messenger and from jihad on HIS path, then wait until
Allah brings forth HIS decision". And Allah does not guide
those who are wicked (Attaubah, 24)

Depart you in both feeling light and heavy, and strive in jihad with your wealth and yourselves in the way of Allah. That it is better for you, only if you know (Attaubah, 41)

For those whose understanding of religion is relatively new, understanding this verse will definitely make a fundamental and narrow understanding of jihad. Even though this verse has the asbabunnuzul that we cannot apply by taken for granted the meaning, which is applied according to the meaning and composition of the sentence alone. Furthermore, understanding the Qur'anic verse requires a lot of approaches, both history, nasah mansuh and takwil.

From this show, the Indonesian people are increasingly wary and the ISIS action is always to be a concern. Moreover, many organizations whose initial aspirations were the same as ISIS, that is Islamic caliphate (khilafah islamiyyah). In addition to the NII derivative organizations, there are also organizations that reasonable to be taken into account as they agree with the ISIS ideology, which are the Indonesian Mujahidin Council (Majelis Mujahidin Indonesia), the Islamic Defenders Front (Front Pembela Islam), the Islamic Da'wah Council (Dewan Dakwah Islam), Hizb ut-Tahrir Indonesia. FPI also agrees with the Islamic Khilafah and Amar makruf nahi mungkar explicitly. This is stated in the FPI's Declaration on ISIS, the contents of which number 5 (five) is that the FPI supports the call and advice of leaders of Alqaedah, Sheikh Aiman Az-zuwahiri that all components of jihad Alqaidah both the forces of Muhammad AlJaulani in Syria and the forces of Abu Bakar Albaghdadi in Iraq, as well as other components of Al-Qaeda Jihad to unite and make relation with all Islamic mujahids in the world to continue jihad in Syria, Iraq, Palestine and other oppressed Islamic countries [8].

The spread of ISIS radical ideology in Indonesia is like a virus that quickly outspread the world. This Information Technology era has contributed to the massive spread as ISIS militants have prepared information technology experts to expand their mission via twitter, Facebook and youtube. Apart from the media, there is the most active site in sympathizing with ISIS, such as www.almustakbal.net (already blocked), www.shoutussalam.com, and www.panjimas.com.

The dissemination of radical ideologies such as ISIS needs to beware by all citizens of the world. Since it 
was founded and appointed Abu Bakar Albaghdadi as Caliph (Khalifah) as designation of Khalifah Fi ad-daulah Al-Islamiyyah fi Al-Iraq wa As-Sham, his actions make him not only the caliph in Iraq and Syria but make himself as al-Khalifatu Lil Muslimin (the caliph of all Muslims) to aggressively outspread throughout the world.

ISIS in a brief time after its birth has shocked the world, the majority of the world's population is troubled that even Muslims themselves are extremely concerned about it. This is because first, ISIS turned out to have succeeded in recruiting thousands of foreign troops; they called themselves mujahidin li nashrati al-islam wa al-muslimin means mujahaidin fighters who aim for the authority of Islam and Muslims.

Second, ISIS in a brief time controlled the territory of Iraq and Syria. Even ISIS's power stretched from the A'zaz region of Halb Province in the north to the Bukmal region in the east bordering Iraq. While in Iraq, it stretches from Falujjah, Ramadi, Kirkuk to Mosul [7].

The struggle that ISIS wants to destroy is different from Al-Qaeda. Alqaeda fights everything related to western interests. However, they still consider friends and relatives with fellow Muslims, while ISIS on various occasions shows that they are fighting those who disagree with their struggle. This is what causes ISIS to be more dangerous than Al-Qaeda.

\section{B. Target of ISIS Ideology Dissemination}

In the present day, crime is not only committed by adults, but also by children [6]. The goal of spreading radical ideologies such as ISIS is all parties and the most important are younger generation, even children. This is because the younger generation has a vital role for the advancement of the nation and is expected to become powerful jihad soldiers on the battlefield. Thus it is not surprising, in several incidents in Indonesia, many young people who are still classified as children based on Law No. 11 of 2012 concerning Juvenile Criminal Justice System are tempted to join ISIS, including among others, a young man from Lamongan, East Java, Wildan Mukhollad, born in 1995, classified as a very young age. As alumni of the Al Islam Islamic Boarding School run by the Amrozi family, Wildan then went to Egypt in 2011, but in 2012 Wildan disappeared and reportedly had followed ISIS and committed jihad in February 2013, he had died and became a suicide bomber in Iraq.

Around the world, young British people recruited by ISIS are young people. His name is Cardiff, 20 years old. Furthermore, the United States young man Douglas Mc. Aithur Mc. Cain, born January 29, 1981, lived sedentary life to Syria and became an ISIS jihadist, was killed in an armed conflict. In Indonesia, according to 2013 Chief of National Police, General Sutarman, about 56 Indonesian citizens are members of ISIS. Young people are easy targets for ISIS recruitment as none other than ISIS recruitment is more massive through cyberspace, where young people often venture into cyberspace that they will often get lost in their exploration and become ISIS followers (Mashuri, 2014:35 39).
What is the potential of campus? As a place of educated people and many young people who are always in touch with cyberspace, they definitely have the potential to become targets. The difference between students and college students is certainly very massive gap in the entry of radical ideology in the campus. Academic freedom and freedom of the academic platform in the campus certainly cannot be restricted, as college students have their own ideology and have the autonomy to develop science and seek knowledge. However, sometimes this is the entry point for radical and anti-Pancasila ideology among young college students.

The author himself had ever accompanied Dr. Ali Masyhar, SH, MH, in the Central Java Regional Police, for the case of college students involved in the NII case, even the author also had a friend with Sugeng who had been brainwashed by senior NII around Semarang. When the author asked the students involved in NII in the Central Java Regional Police regarding the network and whoever the NII virus had affected. The college student involved in the NII network was just quiet and said nothing. It indicated that the way to brainwash is truly extraordinary, that making people willing to lose everything in order to hide their network.

From the results of the questionnaire (mini research) that the author did to 30 students with a background of student activists, found that from some of their observations, the campus became an easy target in the dissemination of radical ideology.

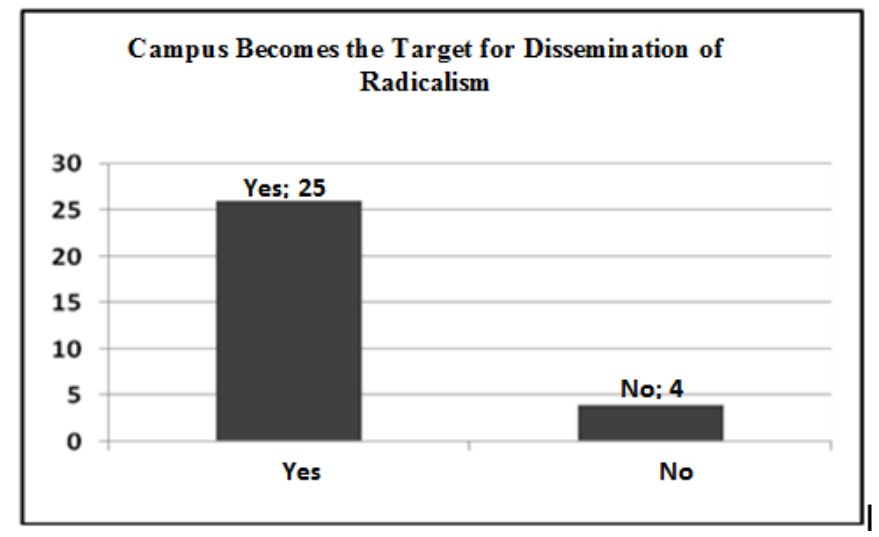

Fig. 1. The opinions of respondents related to the campus as a target of dissemination of radicalism

The table illustrates that out of 30 respondents, 26 respondents responded that campus is the main target for the dissemination of radical ideology. Only 4 are pessimistic if the campus becomes the target. This situation absolutely, when compared with scientific data from existing libraries is very linear. Moreover, it is associated with the strategic role of young people who are the main target for dissemination of ideology, coupled with historical studies that each new ideology will target young people.

The potential of campus to be an easy target for dissemination of radical ideology and the effort to bring radicalism into campus must be a warning for the campus to have awareness and eradication and prevention policies. 
Questionnaires also asked about their opinions whether there had been an effort to spread radicalism on campus, several respondents responded that it had occurred, this was because they consider development of the virtual world of Facebook that some students spread the status of radicalism and share it on their Facebook accounts.

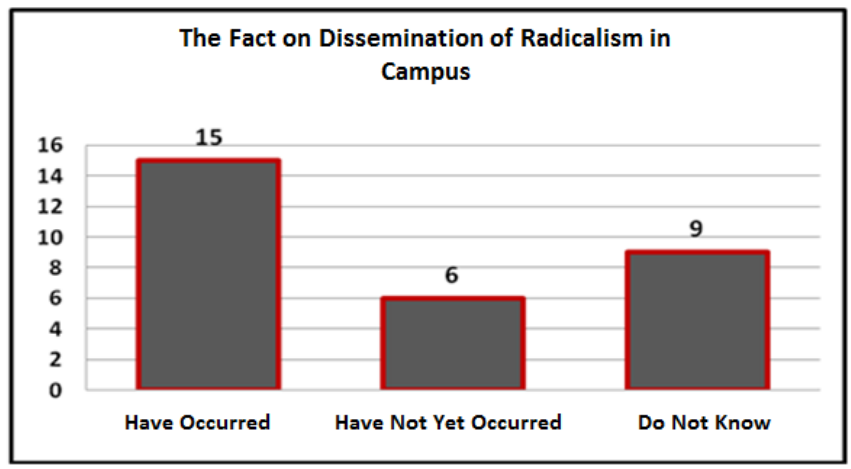

Fig. 2. The fact on dissemination of radicalism in campus

This fact indicates that the majority of respondents responded that dissemination of radical ideology in the campus had occurred even though the scale did not reach terrorism. This denotes the need for vigilance for the entire academic community in the campus against the dissemination of this radical ideology. Never let the space for academic freedom provided in the University statutes become an easy means to spread radicalism.

The dissemination of radicalism is carried out in various ways. According to correspondence, the facilities that can/have the potential used as a way of spreading radical ideas such as ISIS are student discussion forums, religious associations, student organizations, Friday sermons, and social media. When examined comprehensively, the dissemination of radical ideology in the campus can be indirectly carried out in various ways, but the discussion forum is very influential, especially in the matter of planting ideology.

The discussion process must indeed be a concern for University or campus policy makers. As the opinion of the respondents, that the most vulnerable forum for religious discussion used by the dissemination of radicalis are such as Friday sermons, lectures and mentoring religious activities. It is required to conduct supervision of these activities, meaning that people who spread radicalism are prohibited from preaching. Then it requires mentoring, whether the lecturers have a role in mentoring activities or just leve it to the students. If it is left unchecked, it could potentially be a mistaken understanding that leads to radicalism.

Activities such as mentoring or extending the Islamic religion conducted by senior college students certainly need for review. The potential for abuse is extremely higher. The implementation of mentoring system conducted by senior college students is actually good, which is adopting a boarding school system where every senior student becomes a mentor for his classmates. However, the process of being a mentor at the Islamic Boarding School is carried out directly by the caregivers of boarding schools.

\section{CONCLUSION}

The conclusion of the research indicates that there are universities potentially to be the target for dissemination of radicalism committed by ISIS, in addition to universities being a gathering place for young people, it also have facilities that have the potential to be a space for the dissemination of radicalism. The facilities are student organizations, discussion forums, religious study forums such as liqo' activities and mentoring, a cadre unit of Islamic organizations and boarding houses for cadre formation fostered by certain groups.

\section{REFERENCES}

Almawardi, Imam. 2015. Ahkam Sulthaniyyah Sistem Pemerintahan Islam (diterjemahkan oleh Khalifurrahman Fath dan Fathurrahman). Jakarta: Qisthi Press.

[2] Ali, Zainuddin. 2010. Metode Penelitian Hukum. Sinar Grafika: Jakarta.

[3] Ali, As'ad Said. 2014. Al-Qaeda Tinjauan Sosial Politik Ideologi dan Sepak Terjangnya. Jakarta: Penerbit LP3ES.

[4] Kristeva, Nur Sayyid Santoso. 2015. Sejarah Ideologi Dunia. Yogyakarta: Lentera Kreasindo

[5] Latif, Yudi, 2011, Negara Paripurna (Historitas, Rasionalitas, dan Aktualisasi Pancasila), PT. Gramedia Pustaka Utama, Jakarta

[6] Maskur, M.A., \& Subondo, Herry. 2017. Sociological Juridical Analysis on Islamic Boarding School as an Educational Institution for Children Committing Criminal Act in Indonesia. International Journal of Business, Economics and Law, Vol. 12, Issue 4 (Law).

[7] Masyhuri. Ikhwanul Kiram. 2014. ISIS Jihad atau Petualangan. Jakarta: Republika Penerbit.

[8] Muhammad, Reno. 2014. ISIS Kebiadaban Konspirasi Global. Jakarta: PT. Mizan Publika (Noura Books).

[9] Nawawi Arif, Barda. 2010. Masalah Penegakan Hukum dan Kebijakan Hukum Pidana dalam Penanggulangan Kejahatan. Jakarta: Kencana Prenada Media Group.

[10] http://nasional.harianterbit.com, October 28, 2015

[11] http://www.uinsby.ac.id

[12] https://www.youtube.com/watch?v=jUQWOy_E75U

[13] eradajjal. blogspot. co. id

[14] barisanjihad. blogspot.com

[15] www. youtube. com/ watch? v= gdsDFa1MgIA

[16] http://www.muslimdaily. net

[17] http:// jannatullah. blogspot. co.id

[18] www. kominfo.go.id

[19] www.almustakbal.net

[20] www.shoutussalam.com

[21] www.panjimas.com 